\title{
Survival in small cell lung carcinoma after surgery
}

\author{
H RAHBEK SØRENSEN, CLAUS LUND, P ALSTRUP
}

From the Department of Thoracic and Cardiovascular Surgery, University Hospital, Odense, The Department of Pathology, University Hospital, Odense and The Department of Pathology, County Hospital, Holstebro and The Department of Cardiothoracic Surgery, University Hospital, Rigshospitalet, Copenhagen

ABSTRACT In a retrospective study of long term survival in patients with small cell carcinoma of the lung who had been treated purely by surgery, 1820 patients with lung cancer seen during the 15 years 1962-77 were reviewed and reclassified histologically and according to the TNM system. Of these patients, 924 had had resections and 284 exploratory thoracotomies. Cancer chemotherapy was not used in this period and radiotherapy was given only occasionally as palliative treatment. Seventy seven of the patients having pulmonary resections had small cell carcinoma $(8.4 \%)$, and there were six survivors among the 71 with $\mathrm{T}_{1-2}, \mathrm{~N}_{0-1}, \mathrm{M}_{0}$ tumours. The five and 10 year survival rates were both $12 \%$. The histological specimens from these six patients with a small cell carcinoma who survived more than 10 years were re-evaluated and confirmed as small cell by an independent group of pathologists. It seems justified to conclude that a selected group of patients with small cell carcinoma should be treated by surgery alone without adjuvant chemotherapy, which might reduce the long term survival.

The results of surgery for lung cancer have not improved over the years, apart from the reduction of perioperative complications. ${ }^{1}$ There has been a change in the approach to treatment, with a move from surgery alone to chemotherapy and irradiation, or combinations of these three modalities. This is especially so for small cell carcinoma. ${ }^{2-4}$ The histological classification may be difficult, but is of major importance in comparing results from different series. ${ }^{5}$ The TNM classification of small cell carcinoma is superior to staging purely on the basis of limited and extensive disease. ${ }^{6}$ We have found only one purely surgically treated series of patients with small cell carcinomas classified after the publication of the World Health Organisation criteria in 1981. ${ }^{7}$

The aim of this paper is to present the long term survival of an unselected series of patients with lung carcinomas treated purely surgically over 15 years, which we have reviewed and classified afresh on the basis of microscopy. During this period chemotherapy was not used, so small cell carcinomas had been evaluated for surgical treatment in the same way as other types of lung cancer.

Address for reprint requests: Dr H Rahbek Sørensen, Department of Cardiothoracic Surgery, University Hospital, Rigshospitalet, Blegdamsvej 9, DK-2100 Copenhagen, Denmark.

Accepted 13 November 1985.

\section{Patients and methods}

The total number of patients with lung cancer seen at the department of thoracic and cardiovascular surgery in Odense from 1 September 1962 to 31 August 1977 was 1820 after reclassification. Of these, 924 underwent resection, the indication for operation being the possibility of cure. In 284 patients an exploratory thoracotomy was performed and the remaining 612 patients were not operated on. No patient received chemotherapy; a few had palliative radiotherapy after operation, but no combined treatment was planned.

The clinical records of all operated patients were re-evaluated by two surgeons and were reclassified according to the TNM system. ${ }^{8}$ Before operation all patients had chest radiographs performed in two planes and all underwent bronchoscopy. Mediastinoscopy was done in 45 of the 77 patients who had pulmonary resections and in 36 of the 58 patients who had explorations. During operation enlarged lymph nodes were removed and examined separately but proper mediastinal dissection was not performed routinely. The pathological description of the specimen included the tumour, the lymph nodes, and the resection line. In the classification of the primary tumour, $\mathrm{T}_{3}$ tumours could easily be distinguished, whereas discrimination between $T_{1}$ and $T_{2}$ tumours 
was not always possible. Classification according to nodal disease was fairly reliable, but a clearcut distinction between hilar disease and subtle disease of mediastinal nodes was not always possible, and in this way underestimation may have occurred. Classification according to distant metastases was based on the clinical description and the chest radiograph.

All histological specimens were reclassified blindly by one pathologist according to the WHO 1981 criteria. ${ }^{9}$ Among the patients who had explorations no histological material was available in 45 cases. Among the patients who had resections the material was missing in two cases. The microscopic material from the seven patients classified as having small cell carcinoma after the first review and who survived for more than five years was re-evaluated blindly by an independent group of pathologists. The diagnosis of small cell carcinoma of intermediate cell type was confirmed in six patients and changed to poorly differentiated squamous cell carcinoma in one patient.

\section{Results}

Of the 284 patients who had an exploratory thoracotomy, $58(24 \%)$ had small cell carcinoma.

Among the 924 resected tumours, 77 (8.4\%) were small cell carcinomas. In this group one patient classified as $\mathbf{M}_{1}$ had a metastasis removed from the brain before the lung resection. Five other patients were classified as $T_{3}$. None of these six patients survived for one year. Of the remaining 71 patients classified as $T_{1-2}, N_{0-1}, M_{0}$, six have survived-for $10,10,10,13,16$, and 17 years.

Analysis of survival after resection (table 1) for patients with small cell carcinoma compared with those with non-small cell carcinoma showed that $8 \%$ $(6 / 77)$ of all patients with small cell carcinoma survived for five and 10 years, while the corresponding survival rates were $26 \%$ and $18 \%$ respectively for non-small cell carcinoma. The distribution of histological subtypes of small cell carcinoma in relation to lymph node classification is given in table 2 . The metastatic rate is significantly higher in the oat cell group than in the intermediate cell type group $\left(\chi^{2}=\right.$ $6.33 ; p<0.05$ ). All survivors were in the latter group and only at the $N_{0}$ and $N_{1}$ stages. Among the 19 patients at the $N_{2}$ stage only two lived longer than one year and none more than three.

The type of operation is correlated with the histological subtype of the tumour in table 3 . The number of pneumonectomies is significantly higher in patients with oat cell carcinoma than in those with carcinoma of intermediate cell type $\left(\chi^{2}=8.77 ; p<0.01\right)$. Survival was found after segmental resection as well as
Table 1 Survivors after surgical resection for non-small cell and small cell carcinoma

\begin{tabular}{lll}
\hline Duration of survival & \multicolumn{2}{l}{ Number surviving } \\
\cline { 2 - 3 } & $\begin{array}{l}\text { Non-small cell } \\
\text { carcinoma }\end{array}$ & $\begin{array}{l}\text { Small cell } \\
\text { carcinoma }\end{array}$ \\
\hline 1 y & $515 / 847$ & $29 / 77$ \\
3 y & $291 / 847$ & $7 / 77$ \\
5 y & $222 / 846$ & $6 / 77$ \\
$\geqslant 10$ y & $121 / 794^{*}$ & $6 / 77$ \\
\hline
\end{tabular}

*Not all survivors have been observed for 10 years.

Table 2 Relationship between histological subtype and lymph node disease in $T_{1-2}, M_{0}$ small cell carcinoma (numbers in parentheses indicate five year survivors)

\begin{tabular}{lllll}
\hline & \multicolumn{2}{l}{ Number with cell type } & \multirow{2}{*}{ Total } \\
\cline { 2 - 4 } & Oat cell & Intermediate & Mixed & \\
\hline $\mathbf{N}_{2}$ & 13 & 5 & 1 & 19 \\
$\mathbf{N}_{1}$ & 9 & $6(2)$ & 0 & $15(2)$ \\
$\mathbf{N}_{0}$ & 9 & $24(4)$ & 4 & $37(4)$ \\
Total & 31 & $35(6)$ & 5 & $71(6)$ \\
\hline
\end{tabular}

Table 3 Relationship between histological subclassification and type of operation in $T_{1-2}, N_{0-1}, M_{0}$ small cell carcinoma (numbers in parentheses indicate five year survivors)

\begin{tabular}{lllll}
\hline & \multicolumn{3}{l}{ Number with cell type } & Total \\
\cline { 2 - 4 } & Oat cell & Intermediate & Mixed & \\
\hline Pneumonectomy & 25 & $16(3)$ & 3 & $44(3)$ \\
Sleeve resection & 1 & 2 & 0 & 3 \\
Lobectomy & 5 & $14(1)$ & 2 & $21(1)$ \\
Minor resection & 0 & $3(2)$ & 0 & $3(2)$ \\
Total & 31 & 35 & 5 & $71(6)$ \\
\hline
\end{tabular}

after pneumonectomy. One surviving patient had radiotherapy to the mediastinum after pneumonectomy and should be omitted.

\section{Discussion}

Small cell carcinomas constitute about $20 \%$ of all lung carcinomas. ${ }^{10}$ The question of long term survival of patients with small cell carcinoma is controversial: Fox and Scadding ${ }^{11}$ and Mountain, ${ }^{12}$ found no five year survivors after resection among 34 and 41 patients respectively. Other authors ${ }^{73-18}$ have had from $10 \%$ to $25 \%$ of patients surviving after treatment with surgery alone. The different series, however, have been collected over a considerable period and changes in classification have occurred, so direct comparison is difficult. Despite the relatively good interobserver agreement (about $95 \%$ ) when small cell carcinoma is diagnosed as an entity by different pathologists, ${ }^{1920}$ ensuring proper classification of the 
few survivors is crucial in the evaluation of long term survival.

Moreover, in the typing of subgroups greater interobserver variation is generally found. ${ }^{21}$ Consequently, to make sure that the number of long term survivors of small cell carcinoma was not inflated with questionable cases, we asked an independent group of pathologists to classify blindly our microscopical specimens from the surviving patients. In this way one of our original seven cases of small cell carcinoma was reclassified as possible squamous cell carcinoma and we moved it into that group. Exact classification should be easier with resection specimens than with preoperative biopsy material, which is often sparse and crushed, ${ }^{5}$ so the number of long term survivors with small cell carcinoma could be considered to include only definite cases.

We have only intermediate cell type carcinoma represented among our survivors, while others have equal numbers of oat cell and intermediate cell carcinoma, ${ }^{7}$ and differences in prognosis between oat cell and intermediate cell types are unsure. In the present series the oat cell carcinoma was generally in a higher $\mathrm{N}$ stage and extended more centrally. This caused a higher pneumonectomy rate as well as a poorer prognosis.

A good result after treatment of the intermediate cell type by surgery supplemented by chemotherapy was achieved by Hayata et $a^{2}$ : nine of 10 five year survivors had had carcinomas of the intermediate cell type and $10 \%$ of patients with this type survived for more than five years, although this cell type has been said to have a poorer response to chemotherapy than other types. ${ }^{22} \varnothing$ sterlind et $a l^{23}$ on the other hand, found a poor long term survival after chemotherapy alone and also, for the group of "operable" small cell carcinoma, for surgery followed by chemotherapy. Toxic reactions in the bone marrow during chemotherapy are well known complications and may be lethal. ${ }^{24}$ Volk et $a l^{25}$ found that chemotherapy might even increase morbidity and mortality in those patients who were disease free more than 12 months after treatment. The value of chemotherapy, alone or in combination, although it has an indisputable positive effect on median survival, has been disappointing with regard to long term survival. ${ }^{26}$

In our series the TN classification was based on operative findings and pathological material but the staging according to distant metastatis was based on the clinical findings in patients supported by chest radiography. A routine search for dissemination by bone marrow biopsy, peritoneoscopy, and radioactive scanning ${ }^{27}$ or computed tomography ${ }^{28}$ might reduce the number of $M_{0}$ cases and thereby the number of unnecessary operations. ${ }^{8}$ With this in mind, and the attitutes of others (summarised in ref 26), we conclude that a small group of all histological subgroups of small cell carcinoma staged as $\mathrm{T}_{1-2}, \mathrm{~N}_{0-1}$, $M_{0}$ should be treated by surgical resection alone without adjuvant chemotherapy, which might reduce the possibility of long term survival.

We wish to thank Dr RME Seal, department of pathology, Llandough Hospital, Penarth, Glamorgan, UK, for reclassifying part of the histological material. This study has been supported by Foreningen for Kræftens Bekæmpelse, Denmark.

\section{References}

1 Belcher JR. Thirty years of surgery for carcinoma of the bronchus. Thorax 1983;38:428-32.

2 Hayata Y, Funatsu H, Suemasu K, et al. Surgical indications in small cell carcinoma of the lung. Jap J Clin Oncol 1978;8:93-100.

3 Shields TW, Higgins GA, Matthews MJ, Keehn RJ. Surgical resection in the management of small cell carcinoma of the lung. $J$ Thorac Cardiovasc Surg 1982;84:481-8.

4 Shepherd FA, Ginsberg RJ, Evans WK, et al. Reduction in local recurrence and improved survival in surgically treated patients with small cell lung cancer. $J$ Thorac Cardiovasc Surg 1983;86:498-506.

5 Lamb D. Histological classification of lung cancer. Tho$\operatorname{rax} 1984 ; 39: 161-5$.

6 Meyer JA. Effect of histologically verified TNM stage on disease control in treated small cell carcinoma of the lung. Cancer 1985;55:1747-52.

7 Maloney DJL, Morritt GN, Walbaum PR, Lamb D. Histological features of small-cell carcinomas and survival after surgical resection [abstract]. Thorax 1983;38:715.

8 Spiro SG, Goldstraw P. The staging of lung cancer [editorial]. Thorax 1984;39:401-7.

9 World Health Organisation. Histological typing of lung tumours. International classification of tumours. 2nd ed. Geneva: WHO, 1981.

10 Greenberg ER, Korson R, Baker J, Barrett J, Baron JA, Yates J. Incidence of lung cancer by cell type: a population-based study in New Hampshire and Vermont. J Natl Cancer Inst 1984;72:599-603.

11 Fox W, Scadding JG. Medical Research Council comparative trial of surgery and radiotherapy for primary treatment of small-celled or Oat-celled carcinoma of bronchus. Lancet 1973;ii:63-5.

12 Mountain CF. Clinical biology of small cell carcinoma: relationship to surgical therapy. Semin Oncol 1978;5:272-9.

13 Taylor AB, Shinton NK, Waterhouse JAH. Histology of bronchial carcinoma in relation to prognosis. Thorax 1963;18:178-81.

14 Brock Lord. Long term survival after operation for cancer of the lung. Br J Surg 1985;62:1-5.

15 Higgins GA, Shields TW, Keehn RJ. The solitary pulmonary nodule. Arch Surg 1975;110:570-5.

16 Freise G, Gabler A, Liebig S. Bronchial carcinoma and long-term survival. Thorax 1978;33:228-34. 
17 Greschushna D, Maassen W. The importance of histological classification and tumour staging for prognosis after resection of bronchial carcinoma. Thorac Cardiovasc Surg 1980;28:115-9.

18 Shore DSF, Paneth M. Survival after resection of small cell carcinoma of the bronchus. Thorax 1980;35:819-22.

19 Vollmer RT, Ogden L, Grissman D. Separation of smallcell from non-small-cell lung cancer. Arch Pathol Lab Med 1984;108:792-4.

20 Vollmer RT, Birch R, Ogden L, Grissman JD. Subclassification of small cell carcinoma of the lung. Hum Pathol 1985;16:247-52.

21 Hirsch FR, Matthews J, Yesner R. Histopathologic classification of small cell carcinoma of the lung. Cancer 1982;50:1360-6.

22 Davis S, Stanley KE, Yesner R, Kuang DT, Morris JF. Small-cell carcinoma of the lung-survival according to histologic subtype: a Veterans Administration Lung Group study. Cancer 1981;47:1863-6.

23 Østerlind K, Hansen M, Hansen HH, Dombernowsky P,
Rørth M. Treatment policy of surgery in small cell carcinoma of the lung: retrospective analysis of series of 874 consecutive patients. Thorax 1985;40:272-7.

24 Ettinger DS, Lagakos S. Phase III study of CCNU, cyclophosphamide, adriamycin, vincristine, and VP-16 in small-cell carcinoma of the lung. Cancer 1982; 49:1544-54.

25 Volk SA, Maansour RF, Gandara DR, Redmond J. Morbidity in long-term survivors of small cell carcinoma of the lung. Cancer 1984;54:25-7.

26 Hande KR, Des Prez RM. Current perspectives in small cell lung cancer. Chest 1984;85:669-77.

27 Ihde DC, Hansen HH. Staging procedures and prognostic factors in small cell carcinoma of the lung. In: Greco FA, Oldham RK, Bunn PA, eds. Small cell lung cancer. New York: Grune and Stratton, 1981:261-83.

28 Harper PG, Houang M, Spiro SG, Geddes D, Hodson $M$, Souhami RL. Computerized axial tomography in the pretreatment assessment of small-cell carcinoma of the bronchus. Cancer 1981;47:1775-80. 